\title{
Mass Mortality Events of Invasive Freshwater Bivalves: Current Understanding and Potential Directions for Future Research
}

\author{
William G. McDowell ${ }^{1 *}$ and Ronaldo Sousa ${ }^{2}$
}

${ }^{1}$ Department of Biology, Merrimack College, North Andover, MA, United States, ${ }^{2}$ CBMA-Centre of Molecular and Environmental Biology, Department of Biology, University of Minho, Braga, Portugal

\section{OPEN ACCESS}

Edited by:

M. Eric Benbow,

Michigan State University,

United States

Reviewed by:

Philip Barton,

Australian National University, Australia

Traci P. DuBose,

University of Oklahoma, United States

*Correspondence:

William G. McDowell

wgmcdowell@gmail.com

Specialty section: This article was submitted to

Population and Evolutionary

Dynamics,

a section of the journa

Frontiers in Ecology and Evolution

Received: 10 March 2019

Accepted: 19 August 2019

Published: 13 September 2019

Citation:

McDowell WG and Sousa R (2019)

Mass Mortality Events of Invasive

Freshwater Bivalves: Current

Understanding and Potential

Directions for Future Research.

Front. Ecol. Evol. 7:331.

doi: 10.3389/fevo.2019.00331
Mass mortality events, the rapid, catastrophic die-off of organisms, have recently been recognized as important events in controlling population size, but are difficult to quantify given their infrequency. These events can lead to large inputs of animal carcasses into aquatic ecosystems, which can have ecosystem scale impacts. Invasive freshwater bivalves such as the Asian clam Corbicula fluminea, the zebra mussel Dreissena polymorpha, the golden mussel Limnoperna fortunei, and the Chinese pond mussel Sinanodonta woodiana can attain high densities and biomass and play important roles in aquatic ecosystems through filtration, bioturbation, and excretion. Invasive bivalve species can best be described as R-selected species and appear not to have the same tolerance to abiotic stressors as native species, causing them to be prone to mass mortality events in their invasive range. In contrast to their ecological effects while alive, the frequency and impacts of mass mortality events of invasive freshwater bivalves are not well-understood. Here we review the causes and impacts of mass mortality events, as well as identify important questions for future research. Extreme abiotic conditions, including both drought and flooding, as well as high and low temperatures were the primary drivers of mass mortality events. Short-term impacts of mass mortality events include large pulses of nitrogen and increased oxygen stress due to large amounts of soft tissue decomposition, while shells can impact habitat availability and nutrient cycling for decades. Impacts on biological communities (bacteria, fungi, and macroinvertebrates) are less studied but some examples exist concerning $C$. fluminea. Better documentation of mass mortality events, particularly their magnitude and frequency, is needed to fully understand the impacts invasive bivalve species have on ecosystems, especially as climate change may make mass mortality events more frequent and/or have a larger magnitude.

Keywords: boom-bust dynamics, die-off, extreme events, invasive species, non-indigenous species, Corbicula

\section{BACKGROUND}

Mass mortality events, "the rapid, catastrophic die-off of organisms that punctuate background mortality rates" (Fey et al., 2015), have recently been recognized as important events in controlling population size, but it can be difficult to put the significance of these events in a broader context given their infrequency (Fey et al., 2015). A meta-analysis showed that mass mortality 
events are increasing in both frequency and magnitude across several taxa, including marine invertebrates (Fey et al., 2015); however, freshwater invertebrates were not included within this study. For invasive species, research often focuses on quantifying effects as a function of their range, abundance, and per capita impact (Parker et al., 1999). In doing this, much research has focused on their impacts while alive, without capturing the impacts of possible periodic mortality events.

Within freshwater ecosystems, bivalves such as clams and mussels play a critical role in a wide range of ecosystem functions, including filtering bacteria, particulates, and primary producers from the water column, bioturbation via movement and pedal feeding, and excretion of important nutrients such as nitrogen and phosphorus (Covich et al., 1999; Vaughn and Hakenkamp, 2001; Vaughn and Hoellein, 2018). Many of these processes directly benefit humans as ecosystem services, such as removing nutrients and sediment from water (Vaughn, 2018). Globally, freshwater mussels (Bivalvia, Unionida) are among the most threatened organisms on earth (Strayer et al., 2004; Lopes-Lima et al., 2017, 2018) and many populations are experiencing large scale declines (Haag, 2012; Ferreira-Rodríguez et al., 2019). In many ecosystems, declines of native mussels have been coupled with the establishment of invasive bivalve species that evolved elsewhere in the world and now have negative economic and ecological impacts (Strayer and Malcom, 2018).

Invasive bivalves, including the zebra mussel Dreissena polymorpha, the golden mussel Limnoperna fortunei, the Asian clam Corbicula fluminea, and the Chinese pond mussel Sinanodonta woodiana, have been shown to have dramatic ecological and economic impacts on freshwater ecosystems and are among the most widespread and damaging invasive species in the world (Sousa et al., 2014). Many invasive bivalve species have large-scale impacts on ecosystem function (Caraco et al., 1997; Strayer et al., 1999; Zhu et al., 2006) and can act as ecosystem engineers (Sousa et al., 2009). They can also often times reach extremely high densities of several hundreds to thousands of individuals per square meter (Caraco et al., 1997 for D. polymorpha, McDowell and Byers, 2019 for Corbicula sp., Bódis et al., 2016 for Sinanodonta woodiana), and sometimes even on the order to hundreds of thousands of individuals per square meter for the golden mussel Limnoperna fortunei (Sylvester et al., 2007). Invasive bivalves have also been observed to die en masse (Ilarri et al., 2011), with sometimes 90-99\% of individuals dying within a short period of time (Haag and Warren, 2008; McDowell et al., 2017). This leads to millions of individuals dying at once, with their bodies releasing nutrients within a few days (McDowell et al., 2017).

Our understanding of the importance and impacts of animal carcasses in aquatic ecosystems remains incomplete. Pulses of nutrients into systems can have major bottom-up impacts on food webs (Yang, 2004), especially in aquatic systems where nutrients can move rapidly through the food web (Nowlin et al., 2008). Although a great deal of research has focused on the importance of carcasses of anadromous salmon to aquatic ecosystems and adjacent forests (e.g., Helfield and Naiman, 2002; Hocking and Reynolds, 2011) in the Pacific Northwest region of the United States, examples on other faunal groups and continents are less frequent (but see Subalusky et al., 2017). However, recent research has highlighted the importance of the remains of animals in freshwater ecosystems, and the impacts of the reduction of animal remains in freshwater ecosystems due to overall population declines (Wenger et al., 2019). For example, Wenger et al. (2019) estimate that dissolution of mussel shells could have provided $1 \%$ of the total phosphorus load in rivers during median flow and typical shell production rates; periodic mass mortality events that generate more shell might have played a more important role. Even less studied are the possible impacts of massive mortalities by invasive species in the invaded range.

From an ecological theory perspective, invasive bivalves may be prone to frequent, episodic mortality events due to their tendency to be "weedy" $\mathrm{R}$ selected species that have lower tolerance to abiotic stressors (McMahon, 2002), which may make them more prone to "boom-bust" dynamics where populations undergo large fluctuations (Strayer et al., 2017). The "boom-bust" model of invasive species has been documented in a variety of organisms, including plants (Stott et al., 2010), insects (Lester and Gruber, 2016), and molluscs (Moore et al., 2012).

In order to better understand the roles of mass mortality events of invasive bivalves in aquatic ecosystems, here we: 1. Review the known mass mortality events of invasive freshwater bivalves, including their causes, impacts, and whether or not native species were affected; and 2 . Identify nine important questions for future research on mass mortality events of invasive freshwater bivalves.

\section{CAUSES OF MASS MORTALITY EVENTS}

We identified documented mass mortality events of invasive bivalves through a literature review searching for studies examining "mass mortality," "die-offs," or "population declines" of invasive bivalves in freshwater ecosystems using Google Scholar over any time period. In particular, we focused on the following invasive bivalves that are abundant and widespread: the Asian clam Corbicula sp., the zebra mussel Dreissena polymorpha, the golden mussel Limnoperna fortunei, and the Chinese pond mussel Sinanodonta woodiana. All studies identified may be found in Table 1. It is important to note that mass mortality events are not unique to invasive bivalves, and can also occur with native bivalve species (e.g., Vaughn et al., 2015 in Oklahoma, Sousa et al., 2018 in the Iberian Peninsula). While this review focuses on mass mortality events of invasive bivalves, a critical and open research question is to what extent the responses of native and invasive bivalves may differ and or interact (DuBose et al., 2019). Generally speaking, mass mortality events of invasive bivalve species were triggered by extreme abiotic conditions, including drought, flood, extreme high temperatures, and extreme low temperatures (Figure 1).

\section{Drought and High Temperatures}

Drought and high temperatures, which typically co-occurred and therefore cannot be split apart as separate stressors, were the dominant driver of mass mortality events of invasive freshwater bivalves. We found documented high temperature mortality events in the southern United States in particular 
TABLE 1 | Summary of documented mass mortality events of invasive bivalves. Studies are sorted by cause, then species.

\begin{tabular}{|c|c|c|c|c|}
\hline References & Location & Habitat & Species & Cause \\
\hline Golladay et al. (2004) & GA, USA & Stream/river & Corbicula & Drought/heat \\
\hline Gagnon et al. (2004) & GA, USA & Stream/river & Corbicula & Drought/heat \\
\hline Haag and Warren (2008) & $\mathrm{AL}$ and $\mathrm{Ml}, \mathrm{USA}$ & Stream/river & Corbicula & Drought/heat \\
\hline Atkinson et al. (2014) & OK, USA & Stream/river & Corbicula & Drought/heat \\
\hline McDowell et al. (2017) & GA, USA & Stream/river & Corbicula & Drought/heat \\
\hline Mouthon and Daufresne (2006) & France & Stream/river & Corbicula & Drought/heat \\
\hline Foekema et al. (2008) & The Netherlands & Stream/river & Corbicula & Drought/heat \\
\hline Ilarri et al. (2011) & Portugal & Stream/river & Corbicula & Drought/heat \\
\hline Bódis et al. (2014a) & Hungary & Stream/river & Corbicula, S. woodiana & Drought/heat \\
\hline Balogh et al. (2008) & Hungary & Lake/Reservoir & Zebra mussel & Drought/heat \\
\hline Churchill (2013) & TX and OK, USA & Lake/Reservoir & Zebra mussel & Drought/heat \\
\hline Churchill et al. (2017) & TX and OK, USA & Lake/Reservoir & Zebra mussel & Drought/heat \\
\hline White et al. (2015) & MI, USA & Lake/Reservoir & Zebra mussel & Drought/heat \\
\hline Sousa et al. (2012) & Portugal & Stream/river & Corbicula & Flood \\
\hline Castañeda et al. (2018) & Canada & Stream/river & Corbicula & Low temperatures \\
\hline Smith et al. (2018) & WI, USA & Stream/river & Corbicula & Low temperatures \\
\hline Werner and Rothhaupt (2008) & Switzerland & Lake/Reservoir & Corbicula & Low temperatures/desiccation \\
\hline Leuven et al. (2014) & The Netherlands & Lake/Reservoir & Corbicula, Zebra mussel & Low temperatures/desiccation \\
\hline
\end{tabular}

(Georgia: Gagnon et al., 2004; Golladay et al., 2004; McDowell et al., 2017, Figure 2A; Alabama and Mississippi: Haag and Warren, 2008; Oklahoma: Atkinson et al., 2014; Vaughn et al., 2015; Texas and Oklahoma: Churchill, 2013; Churchill et al., 2017). High summer temperatures were also associated with mortality events for C. fluminea in both Portugal (Ilarri et al., 2011) and France (Mouthon and Daufresne, 2006), as well as a mortality event in Hungary which affected Corbicula sp., S. woodiana, and native mussels (Bódis et al., 2014a, Figure 2B). During drought events, small streams may be impacted more heavily, as they are more prone to dewatering; following a drought in Alabama and Mississippi, C. fluminea populations declined $90-98 \%$ in small streams, but significantly increased in two of the three large river sites studied (Haag and Warren, 2008).

The exact trigger for the mortality can vary from case to case. High temperatures and drought can lead to bivalves being stranded on sand bars or within disconnected pools as flows decline (Atkinson et al., 2014), or even mortality of individuals still within flowing water, due to high temperatures and low dissolved oxygen concentrations (Foekema et al., 2008 as cited in Ilarri et al., 2011; Leuven et al., 2014; McDowell et al., 2017). In estuarine areas, drought can lead to increases in salinity, which may be a contributing factor to Corbicula mass mortality events within the Minho River in Portugal (Ilarri et al., 2011). Within lakes, drought can lead to water level fluctuations, leaving individuals stranded, as was observed in a zebra mussel mortality event in Lake Balaton, Hungary (Balogh et al., 2008) and in Lake Texoma on the border between Texas and Oklahoma, USA (Churchill, 2013; Churchill et al., 2017). Mortality events may occur regularly during heat waves and with a large enough magnitude to control population sizes, as Ilarri et al. (2011) noted that the lowest observed population densities of C. fluminea corresponded to years with summer heat waves. Mortality events can also occur at temperatures that are "sub-lethal" per laboratory experiments (White et al., 2015), emphasizing the importance of field research on these events.

\section{Flooding}

Flooding, the other hydrologic extreme, can also lead to mass mortality events. Floods typically do not directly kill the bivalves, but instead transport them to unsuitable habitats during high flows after which they are stranded when flood waters recede. High flow events can play an important role in controlling the distribution of a bivalve within a river (Strayer, 1999), and can lead to mass mortality events of invasive species (Sousa et al., 2012, Figure 3). Flooding during the winter months in northern Portugal led to deposition of up to 2,200 individuals $\mathrm{m}^{-2}$ and $10,200 \mathrm{~g}^{-2}$ wet biomass on adjacent river banks. Corbicula fluminea was the most common species transported during flood mortality events, both by biomass and density, despite $C$. fluminea not being the dominant bivalve at some of the study sites (Sousa et al., 2012).

\section{Low Temperatures}

Extreme cold can also lead to mass mortality events of freshwater bivalves. Though minimum temperatures have been shown to be an important controller for the distribution of $C$. fluminea through modeling (McDowell et al., 2014) mass mortality events induced by low temperature are often associated with human manipulations of temperature or water level. In Europe, an extremely cold winter coupled with low water levels in Lake Constance led to a $99 \%$ mortality rate for Corbicula that were either stranded or in water up to $3 \mathrm{~m}$ deep (Werner and Rothhaupt, 2008). Similarly, low water levels and cold temperatures led to high mortality of zebra mussels within 


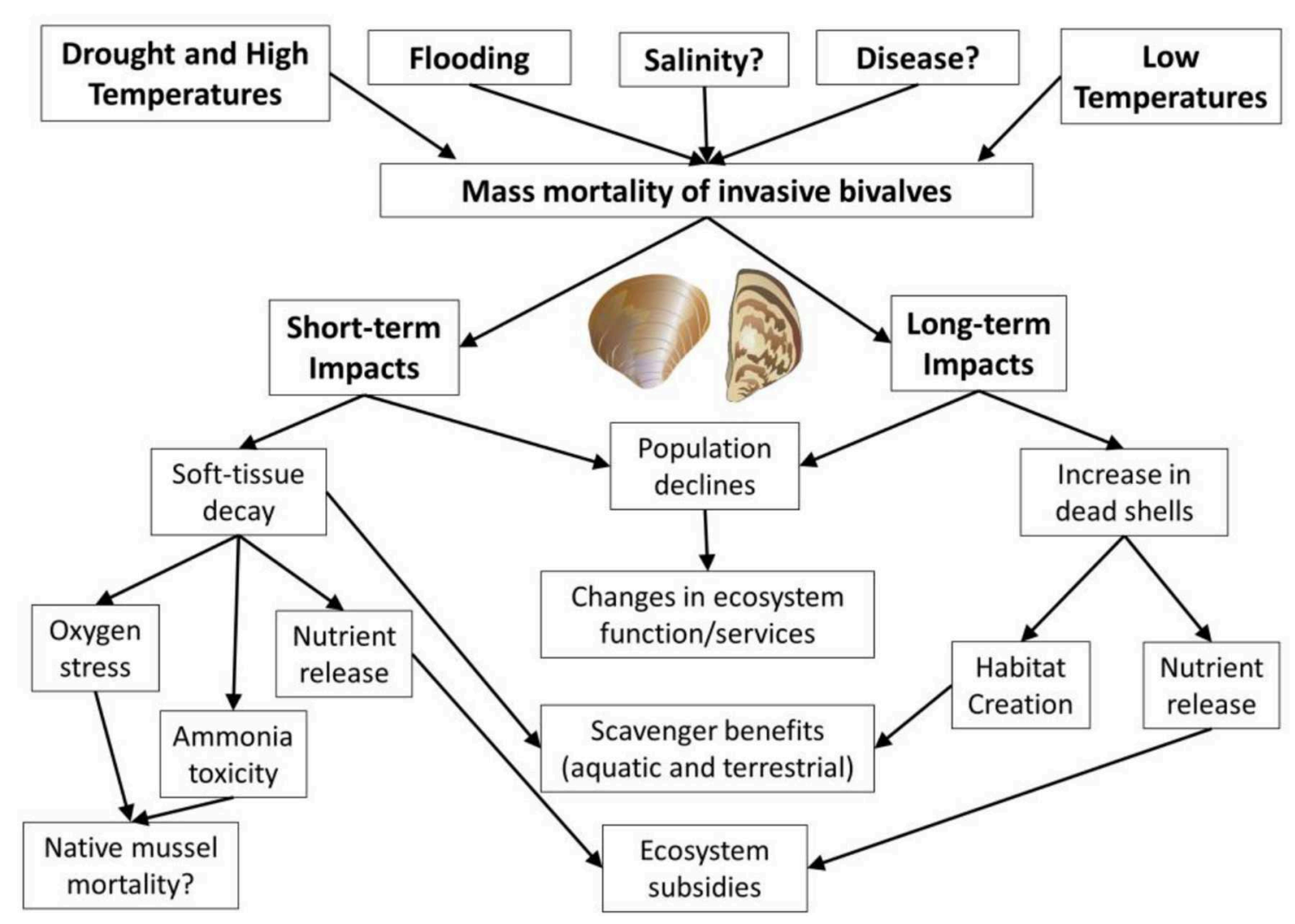

FIGURE 1 | Conceptual diagram of the causes of mass mortality events of invasive bivalves, as well as their short- and long-term impacts. Disease and salinity are included as potential causes of mass mortality events, but have not been documented. Repeated mass morality events could drive down population sizes, particularly if their magnitude or frequency increases due to climate change, though mass mortality events driving long term population declines is hypothetical. Images of Corbicula and zebra mussels are courtesy of the IAN Symbol Libraries (http://ian.umces.edu/symbols/).

impounded sections of the Rhine and Meuse Rivers in the Netherlands (Leuven et al., 2014). The combination of water level drawdowns and low temperatures has been used as a mechanism to control zebra mussel populations (Grazio and Montz, 2002, as cited in Leuven et al., 2014). Conversely, while industrial cooling water plumes may provide thermal refuge for invasive species in areas that are otherwise climatically unsuitable, the cessation of industrial activities can lead to rapid extirpation of populations that relied on the artificial warming to persist. Both individuals and populations can thrive in thermal effluent-one study in the River Shannon, Ireland found that within thermal plumes individuals were more than twice as large by length and body mass, densities were more than 13 times higher, and biomass was nearly 50 times higher (Penk and Williams, 2019). In North America, a population of Corbicula was well-established within the St. Lawrence River in the cooling water plume of a power plant (Simard et al., 2012), but a rapid extirpation followed the decommissioning of the power plant (Castañeda et al., 2018). Mortality events can also occur despite thermal refuge during particularly severe winters, as was documented in the Great Lakes region of the United States with a near extirpation of Corbicula in the Fox River (Smith et al., 2018).

\section{IMPACTS OF MASS MORTALITY EVENTS}

The most immediate response to mass mortality events is the input and subsequent decomposition of dead tissue into ecosystems (Figure 1). The largest bivalve mortality event documented was caused by drought conditions in the Danube River and created an input of over $20-30 \mathrm{~kg} \mathrm{~m}^{-2}$ of wet biomass (which includes shells) and over $1,000 \mathrm{~g} \mathrm{~m}^{-2}$ of ash free dry mass at the sites with the highest densities of invasive bivalves (Bódis et al., 2014a). This mortality event primarily affected the Chinese pond mussel $S$. woodiana, but also included two other invasive bivalves: Corbicula sp. and the zebra mussel D. polymorpha. The decay of soft tissues can be quite rapid, on the order of days (McDowell et al., 2017), and this rapid decay, particularly during warm summer months, could exacerbate already stressful oxygen conditions (Gagnon et al., 2004; McDowell et al., 2017).

\section{Short-Term Effects}

During the decay of soft tissues decay, large amounts of nutrients are released, creating a pulse of resources (Sousa et al., 2012). This can lead to large scale shifts on both a local and ecosystem level. McDowell et al. (2017) estimated that a mortality event of $\sim 100$ million Corbicula released $\sim 751 \mathrm{~kg}$ of carbon, $180 \mathrm{~kg}$ of nitrogen, 

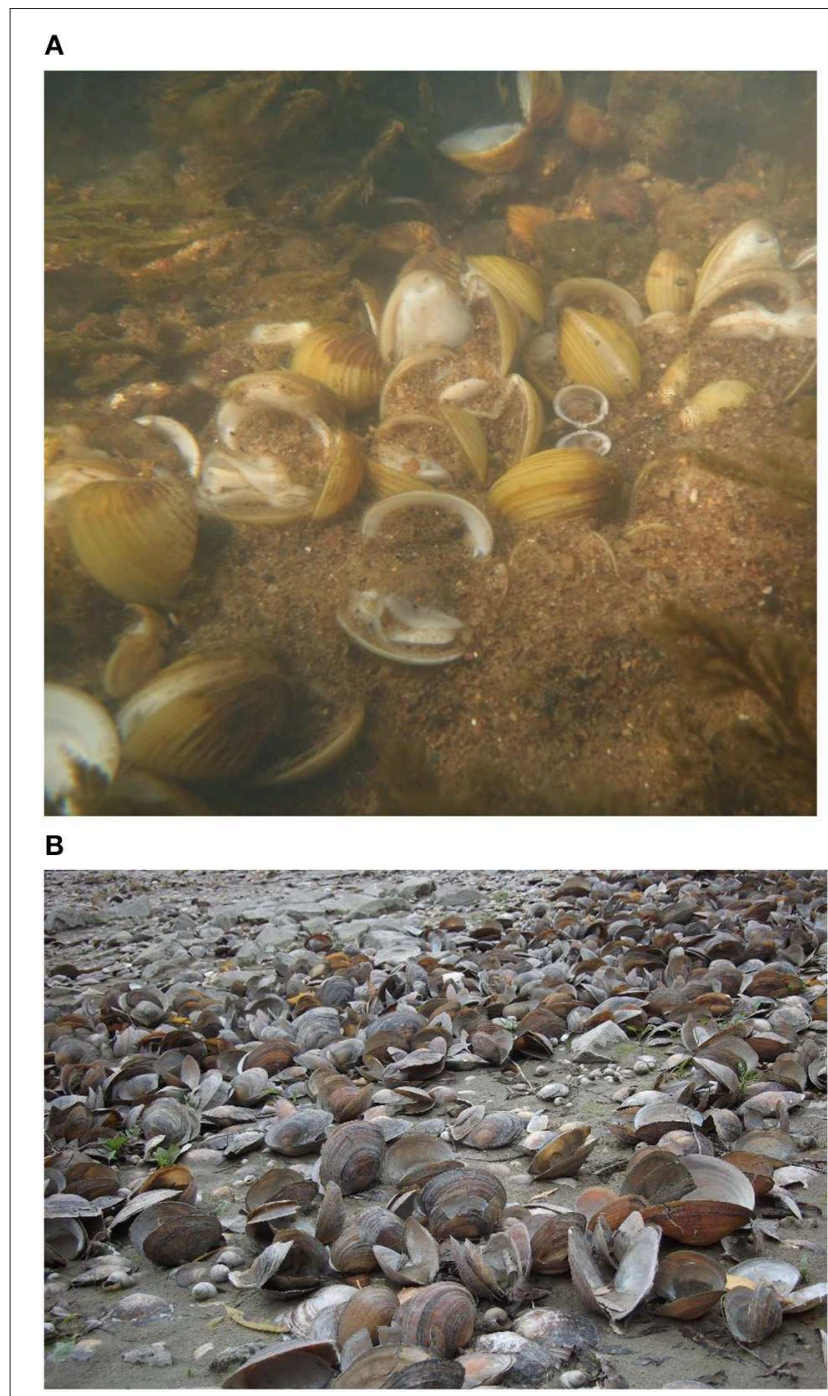

FIGURE 2 | (A) Corbicula die-off in Georgia USA caused by a summer drought, described in McDowell et al. (2017). Note the presence of soft tissue. (B) Sinanodonta woodiana die-off in the Danube River (Hungary) after a drought in 2011. Described in Bódis et al. (2014a).

and $45 \mathrm{~kg}$ of phosphorus as soft tissues decayed. The release of nutrients from a mass mortality event can lead to potentially toxic concentrations of unionized ammonia for unionid mussels, in both the water column (Cherry et al., 2005) and the porewater of sediment (Cooper et al., 2005). However, in a manipulative study simulating a die-off of $C$. fluminea in Minho River (Iberian Peninsula) no changes were detected in the structure of aquatic microbial and invertebrate communities nor litter breakdown rate (Novais et al., 2017).

\section{Long-Term Effects}

The impacts of the decay of soft tissue can be quite large, but short lived, whereas the impacts of shells could extend for decades, given their slow breakdown rate (Strayer and Malcom, 2007; Ilarri et al., 2015). The time frame for the impact of additional

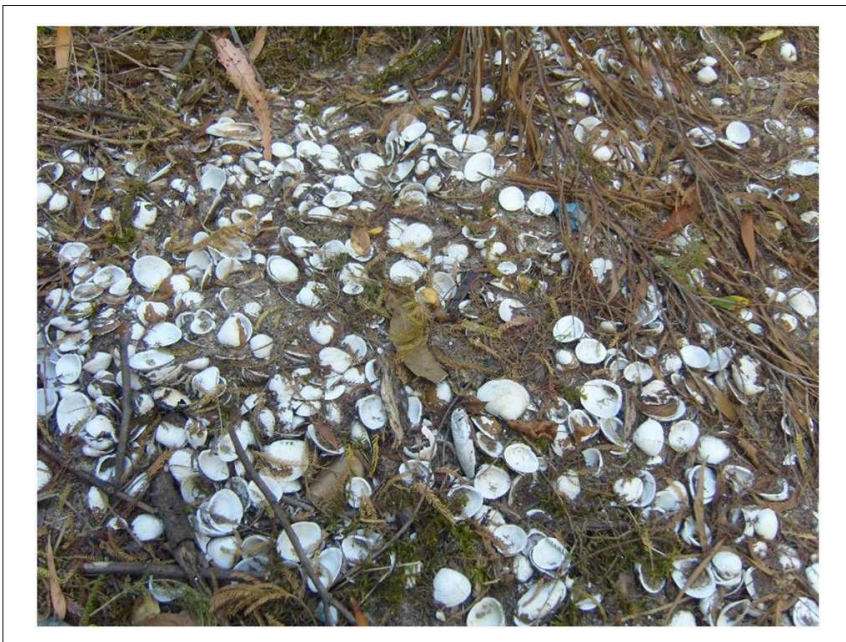

FIGURE 3 | Accumulation of C. fluminea after the 2001 flood in the banks of Minho River. This photo was taken in 2014, 13 years after the flooding, showing the longer-term impacts that additions of shells can have on an ecosystem.

shells can vary substantially depending on whether or not they are found in a terrestrial or aquatic ecosystem, as the decay rate for a variety of bivalve shells (including C. fluminea) is six to twelve times faster in aquatic systems than in terrestrial (Ilarri et al., 2015). Shells, and the trickled release of nutrients, could play an important role in the biogeochemistry of rivers and adjacent flood plains, as bivalve shells can provide significant storage of nutrients, particularly carbon and nitrogen (Vaughn et al., 2015). While shells are relatively poor in both nitrogen and phosphorus $[\sim 1 \% \mathrm{~N}$ and $0.01 \% \mathrm{P}$ for unionid mussels Christian et al., 2008; Atkinson et al., 2010] compared to soft tissue, the sheer mass of shells can provide a significant release of nutrients over time. Wenger et al. (2019) estimated that based on historical densities, the breakdown of mussel shells once provided $\sim 1 \%$ of the total phosphorus load in rivers in the southeastern United States.

\section{Habitat Creation}

The shells of invasive freshwater bivalves can alter the physical habitat within a river, contributing to their role as ecosystem engineers (Sousa et al., 2009). Within the Danube River, empty bivalve shells increased the abundance of a variety of macroinvertebrates. For rivers that are dominated by fine sediment, these shells can provide important habitat for benthic invertebrates and increase their abundance and biomass (Bódis et al., 2014b). Other studies have shown that shell density of C. fluminea is positively associated with biomass, diversity, and density of macroinvertebrates (Ilarri et al., 2012). Shells resulting from die-offs can also have significant effects on estuarine and freshwater macroinvertebrates than can use them as substrate or as refuge from predators (e.g., Ilarri et al., 2012, 2014, 2018; Bódis et al., 2014b; Novais et al., 2015). 


\section{Foodweb Alterations}

Given the importance of filter feeding bivalves in aquatic foodwebs (Vaughn and Hakenkamp, 2001; Vaughn and Hoellein, 2018), it is unsurprising that mass mortality events would alter foodwebs. We have identified two main ways these foodweb alterations can occur: direct benefits to scavenging organisms and ecosystem subsidies from aquatic to terrestrial ecosystems.

\section{Scavenger Benefits}

The addition of soft tissue should be a benefit for scavenging species as well, though published reports of this are limited. Mouthon (2001) reported that soft tissue from Corbicula mortality events was consumed by silurid fishes, though to our knowledge that is the only published account documenting this behavior. Anecdotally, researchers and fishermen have reported estuarine fish moving upstream in Portuguese rivers to consume C. fluminea corpses (Sousa personal observation) and within Georgia rivers, flocks of crows have been observed consuming dead Corbicula that were stranded on a sandbar (McDowell personal observation). Any aquatic scavengers such as crayfish ought to benefit as well, but again, this has not been reported in the literature and remains an open question (see below).

\section{Ecosystem Subsidies}

Nutrients from bivalve decay often cross ecosystem boundaries, providing important subsidies that span the terrestrial aquatic interface. Subsidies from aquatic to terrestrial systems play an important role in many ecosystems, often through anadromous fish such as salmon (Helfield and Naiman, 2002). Mass mortality of invasive freshwater bivalves, particularly through drought or flooding, can lead to ecosystem subsidies of energy and nutrients to terrestrial ecosystems (Sousa et al., 2012; Bódis et al., 2014a, Figure 3). Addition of carrion can impact both nutrient dynamics and communities, as two studies (Novais et al., 2015, 2017) simulating massive die-offs of Corbicula in terrestrial ecosystems after floods showed clear effects on soil chemistry, fungal biomass, and bacterial, fungal, and macroinvertebrate communities. Pulses of nutrients could also increase insect emergence rates in response to additions of phosphorus (Mundie et al., 1991) and both nitrogen and phosphorus (Blumenshine et al., 1997) in experimental stream mesocosms. These higher emergence rates could be an additional way that mass mortality events strengthen subsidies to terrestrial ecosystems, as these insects provide an important food source for riparian predators (Baxter et al., 2005).

\section{Alterations to Ecosystem Function}

Given the importance of filter feeding bivalves in aquatic ecosystems (Vaughn and Hakenkamp, 2001; Vaughn, 2018), including filtration, bioturbation, and nutrient storage, a mortality event can also dramatically alter ecosystem function. For example, within a Georgia River, overall filtration rates by Corbicula dropped $99.6 \%$ following a mass mortality event (McDowell et al., 2017). Filtration is a particularly important function of freshwater bivalves, as it removes particles from the water column and connects the water column and benthic food webs (Vaughn and Hakenkamp, 2001). Few studies have focused on shifts in ecosystem function following mortality of invasive freshwater bivalves, but Vaughn et al. (2015) showed that multiple severe droughts over 20 years caused native mussel mortality that substantially reduced the ecosystem function they provided. Losses were disproportionately felt by thermally sensitive species, which had higher percentages of both nitrogen and phosphorus in their tissues (Atkinson et al., 2014). These impacts are driven by the massive decline in population size, and therefore the overall role of the species in the ecosystem, and can be shortterm and transient if the populations recover, or long-term if the population size remains low or is unable to fully recover due to repeated mortality events. It is unclear if these changes at the ecosystem level will return systems to function closer to their pre-invasion status thanks to the diminished role of invasive species, or if the dramatic decline in filter feeding bivalves will push these systems farther from historical function, even though the dominant bivalves are invasive. Although we are not aware of quantitative studies, similar effects are possible in response to massive declines in density and biomass of dominant invasive freshwater bivalves after massive die-offs.

\section{OPEN QUESTIONS}

In attempting to understand the overall causes and impacts of mass mortality events of invasive freshwater bivalves, we identified several important open questions which researchers should/may address in future studies.

\section{How Frequent Are Mass Mortality Events of Invasive Bivalves?}

To date, most research has focused on quantifying the magnitude and impacts of mass mortality events, rather than their frequency. In addition to the impacts described above, if ecosystems are experiencing regular mortality events, this could also lead to depressed population sizes, and therefore reduce the impacts of invasive species on ecosystem function. Ilarri et al. (2011) found some indication that mass mortality events temporarily depressed population sizes, as C. fluminea densities were the lowest in years following notable heat waves. Overall, it is not clear if mass mortality events are unusual, and best described as a "solitary boom-bust" model in which the population of an invasive expands rapidly, only to decline (Strayer et al., 2017), or if mass mortality events are regular occurrences, best fitting either the "recurrent" or "cyclic" models of boom-bust dynamics where population declines are occurring at least twice, and may occur at regular intervals (Strayer et al., 2017).

The responses of the invasive bivalves to mortality events may vary due to different life spans, with $S$. woodiana having a much longer life span [ $\sim 12$ years Dudgeon and Morton, 1983], than Limnoperna fortunei [2-3 years Ricciardi, 1998] or Corbicula and zebra mussels [ 3-5 years McMahon and Bogan, 2001; Strayer and Malcom, 2006], so it would be expected that the recovery trajectories differ as well. For several of these species, we do not have a long enough period of monitoring to determine long term responses to mass mortality events. In addition to possible differences in responses and recovery from mortality 
events at the species level, populations from different latitudes or subjected to different abiotic conditions (e.g., food resources, altitude; Crespo et al., 2015) may respond differently following a mortality event. Assuming that invasive populations are able to recover, the frequency of mass mortality events fundamentally alters the balance of the impacts invasive bivalves have while alive (filtration, storage and excretion of nutrients, bioturbation) and the impacts they have during mass mortality events (nutrient release, availability of empty shells, loss of filtration). A critical component to answering this question will be better monitoring of mass mortality events; for Corbicula sp., for example, anecdotal evidence indicates that mortality events are relatively common, although they are not well-described in the literature (McDowell et al., 2017). In some cases, mortality of invasive species is only briefly described as part of a study more heavily focused on native species (e.g., Vaughn et al., 2015). In order to better assess the impact and novelty of mass mortality events as part of our overall understanding of the impact of invasive species, better quantitative documentation is needed, and in particular we must know:

\section{Are Native Species Affected Similarly to Invasive Bivalves?}

Invasive species are often considered "weedy," with high reproduction rates but poorer tolerance to stressful abiotic conditions than native species, so therefore ought to experience more frequent mortality events (McMahon, 2002). It is important to note, however, that native species do not represent a homogenous group. Within the United States, the native unionid mussels vary substantially in their ability to tolerate a wide variety of stressors such as desiccation, high temperatures, or low dissolved oxygen (Haag, 2012). Differences in abiotic tolerances should lead to differences in the frequency and magnitude of mortality events in communities dominated by invasive species compared to those with an intact mussel community, especially as an intact native community ought to have a more heterogeneous response to abiotic stressors. Using a trait based framework for the bivalve community as a whole could be an illuminating way to compare the differing roles in and impacts on ecosystems that native and invasive bivalves have in the face of extreme events (de Bello et al., 2010). This approach could lead to broader, more generalizable results than explicit pairwise comparisons of native and invasive species (McGill et al., 2006). Few studies have quantified the mortality of both native and invasive bivalves, but those have generally shown a higher mortality rate for the invasive species induced by both drought (Haag and Warren, 2008; Bódis et al., 2014a) and flood (Sousa et al., 2012). In contrast to the "missing dead"-a decline in the number of animal carcasses in aquatic ecosystems due to widespread population declines-described by Wenger et al. (2019), if mass mortality events of invasive species are occurring more frequently or to a larger magnitude than we would expect in an uninvaded community, mortality events could represent a source of "found dead" instead, increasing overall inputs of shell and soft tissue into aquatic ecosystems. While baseline mortality would be contributing shell and soft tissue, repeated massive mortality followed by rapid population growth could increase the overall amount of inputs of tissue and shell into the system.

\section{Is Corbicula sp. Less Tolerant to Abiotic Stressors Than Other Invasive Bivalves?}

Most of the documented mass mortality events of invasive bivalves are for Corbicula sp., and include populations in Europe and North America. A key question that remains to be answered is if Corbicula is particularly vulnerable to mass mortality events or whether Corbicula dominates studies of mass mortality of invasive bivalves because it has been a research focus for multiple groups in Portugal, Georgia, and Oklahoma. Many of the documented mass mortality events occurred in the southern United States or in southern Europe-is the frequency of mass mortality events a product simply of the extreme heat during the summers in these regions? Mortality events for Corbicula were also primarily in lotic systems, so it is possible that populations in lotic systems are more vulnerable due to fluctuations in water levels and possibly food resources, which will decrease the physiological capacity to deal with a stressful event such as heatwaves. In some instances, mortality events were associated with cessation of flow, creating disconnected pools which often led to mortality of native mussels as well (Atkinson et al., 2014). This could lead to both high temperature and low oxygen, though Corbicula sp. is more tolerant of hypoxia than the zebra mussel at temperatures up to $25^{\circ} \mathrm{C}$ (Matthews and McMahon, 1999). Using laboratory experiments to better define the tolerance of Corbicula to stressful abiotic conditions, particularly high temperatures and low dissolved oxygen, is particularly important to help protect and conserve native bivalves, as the mortality of Corbicula could exacerbate the negative impacts of mass mortality events on native species via increased oxygen stress (Gagnon et al., 2004 in south Georgia) and toxic concentrations of ammonia (Cherry et al., 2005; Cooper et al., 2005).

In contrast, we did not find any documented mass mortality events of $L$. fortunei and a small number impacting $D$. polymorpha. Further research is needed in order to determine if L. fortunei and D. polymorpha follow similar patterns to Corbicula or S. woodiana, which have large-scale mortality events. The golden mussel in particular appears to be very tolerant of a wide range of abiotic conditions, including high temperatures, low dissolved oxygen, and acidic water (Boltovskoy et al., 2006; Karatayev et al., 2007), when compared to other invasive bivalves, including $D$. polymorpha. Given their robust tolerance to abiotic stressors, L. fortunei may be particularly unlikely to experience mass mortality events. The zebra mussel D. polymorpha, on the other hand, has experienced large population declines in recent years, though without clear cut mass mortality events.

\section{Do Salinity Fluctuations Trigger Mass Mortality Events?}

For freshwater species expanding into estuarine environments, salinity is an important controller of distributions. It is also highly dynamic, with both regular fluctuations due to tides, as well as human alterations and extreme events. Salinity appears 
to be particularly important in controlling the distribution of the golden mussel Limnoperna fortunei in estuaries (Angonesi et al., 2008). Corbicula sp., on the other hand, appear to be tolerant to a wide range of salinities in estuaries, with a higher tolerance of $20 \mathrm{ppt}$ during cooler winter months than during summertime conditions ( $\sim 15 \mathrm{ppt}$ ) (Ferreira-Rodríguez and Pardo, 2016), though salinity fluctuations in the lower portion of the Minho estuary were hypothesized as a potential contributor to a mortality event during an extreme heat wave and drought in Portugal (Ilarri et al., 2011). Given that salinity can control the distribution of freshwater invasive bivalves, and can vary greatly due to storms, alterations to land use, and even seasonal shifts in river discharge, salinity should be a potential trigger of mass mortality events. However, to date, none have been documented. This topic requires additional study, and our understanding of the role of salinity in controlling the distribution of invasive bivalves lags behind other abiotic factors such as temperature (Feng and Papeş, 2017).

\section{What Role, If Any, Do Disease Outbreaks Play in Mass Mortality Events of Invasive Freshwater Bivalves?}

Our understanding of disease induced mass mortality of freshwater bivalves in general is limited, although mass mortality events driven by disease outbreaks have been shown in native unionid mussels (Carella et al., 2016) and marine bivalves such as oysters (Burreson and Ragone, 1996; Lacoste et al., 2001). Invasive species often leave behind their parasites (e.g., Blakeslee et al., 2008, 2012), so parasitic species that act as controls in the native range may simply not be found in the new invasive range. However, genetic diversity of invasive species is often lower than in their native range due to founder effects (Sakai et al., 2001), and this lack of genetic diversity should make them more vulnerable to disease outbreaks. Corbicula, as a species that is entirely androgenetic clones in the invasive range in both North America (Lee et al., 2005) and in Europe (Sousa et al., 2007; Gomes et al., 2016), ought to be extremely vulnerable to disease outbreaks, but to our knowledge, none have been demonstrated. There is also the possibility for the transmission of diseases between native and invasive bivalves, though this has not been documented; the transmission of new diseases by invasive species can have substantial negative impacts on native species, however (e.g., Andreou et al., 2012).

\section{How Will Climate Change Alter the Frequency and Magnitude of Mass Mortality Events?}

Climate change is predicted to have a wide variety of impacts on invasive species (Hellmann et al., 2008), including altered distributions of existing invasive species. For some invasive bivalves, warming temperatures have opened additional habitats that had previously been unsuitable climatically due to minimum temperatures (McDowell et al., 2014). Expanding into newly suitable habitats may make invasive bivalves vulnerable to occasional extreme cold, leading to mortality events, similar to those documented in the Great Lakes region of the United States (Smith et al., 2018). Within existing populations, higher temperatures could lead to more frequent mortality events during the summer, such as those observed by McDowell et al. (2017). Finally, both drought and flooding were important causes of mortality events for both native and invasive bivalves. Given that climate change is forecasted to increase the intensity of rain events but reduce their frequency (Trenberth, 2011), both drought- and flood-induced mass mortality events are likely to become more common.

\section{Will the Occurrence of Die-Offs and Ecological Impacts be Similar in the Native and Invaded Range?}

To our knowledge, no research has documented mass mortality events of invasive bivalve species within their native range, let alone compared the frequency and magnitude of mass mortality events between the native and invaded range. Comparisons of mass mortality events between the two ranges would allow us to determine if massive die-offs are more common in the invaded range than in the native range. In theory, invasive species would be less adapted to the abiotic conditions in their invasive range as they did not evolve there. Because invasive species can undergo rapid evolution, however, invasives may be as well-adapted to a local environment as native species (Oduor et al., 2016). If differences exist between the native and invasive ranges, the impact of invasive bivalve species on communities and ecosystem function may vary dramatically in the invasive range compared to the native. It should be noted, however, that this is currently speculative for invasive freshwater bivalves, but deserves future attention.

\section{Which Organisms Benefit From Mass Mortality Events?}

Scavengers ought to exploit the availability of fresh carrion during mortality events, though this has not been established in the literature aside from one report (Mouthon, 2001), perhaps due to the difficulty in capturing transient effects caused by mortality events. For many other taxa the impacts have not been tested or have had inconclusive results. Within terrestrial systems, invertebrates clearly responded to a simulated mortality event, with higher diversity and density that scaled with higher inputs of carrion (Novais et al., 2015). However, a manipulative experiment in a flowing river found no difference in fungi, invertebrates and in decomposition rates (Novais et al., 2017). The responses to mortality events may be highly context dependent, with impacts in lotic systems being less pronounced than those in lentic or terrestrial environments. With inputs into terrestrial systems, there is evidence that mortality events can alter the abundance and biomass of aboveground consumers (Novais et al., 2015), but impacts on belowground communities have yet to be addressed. Further manipulative experiments are needed to fully explore the impacts mortality events have on other communities, in 
particular to quantify what other organisms are benefitting from carrion inputs.

In addition to trophic benefits, the mass mortality of invasive bivalves may provide competitive release for native species if they are able to survive the trigger of the mortality event, as invasive species often compete with natives. Corbicula may compete with native mussels for seston food resource (Leff et al., 1990), and have been shown to lead to lower survival and growth rates of native mussels (Ferreira-Rodríguez et al., 2018) and high densities may reduce the survival of mussel glochidia (Modesto et al., 2019). Zebra mussels compete with native species for both food resources (Baker and Levinton, 2003) and space (Lauer and Spacie, 2004). A mass mortality event of invasive bivalves could lead to higher survival, growth, and reproduction of native bivalves.

\section{How Long Do Effects Remain in the Ecosystem?}

Soft tissue from bivalves will be rapidly consumed or decompose but on the other hand, the shells can persist for several decades (see above). Additionally, the shells of Corbicula sp. are thicker, and more resistant to decay than those of some native species (Ilarri et al., 2019). For both soft tissue and shells the decay rates are highly context dependent-for example, if shells are deposited in areas with high current velocity the decomposition rate will be very different than if shells are deposited on river banks during floods. Similarly, decomposition rates may also be very distinct in different climatic regimes-in areas with more precipitation, decomposition ought to be much faster than in more arid ecosystems. We need quantitative studies to assess the persistence of the impacts associated with mass mortality events of invasive bivalves. In addition, effects may vary from species to species. For example, bivalves with thicker or harder shells, will in theory, take more time to erode and so persist for more time in the system. Longer term monitoring of locations affected by mass mortality events may be needed to understand longer term impacts, especially within terrestrial systems.

\section{REFERENCES}

Anderson, S. C., Branch, T. A., Cooper, A. B., and Dulvy, N. K. (2017). Blackswan events in animal populations. Proc. Natl. Acad Sci. U.S.A. 114, 3252-3257. doi: 10.1073/pnas.1611525114

Andreou, D., Arkush, K. D., Guégan, J. F., and Gozlan, R. E. (2012). Introduced pathogens and native freshwater biodiversity: a case study of Sphaerothecum destruens. PLoS ONE 7:e36998. doi: 10.1371/journal.pone.0036998

Angonesi, L. G., Rosa, N. G. D., and Bemvenuti, C. E. (2008). Tolerance to salinities shocks of the invasive mussel Limnoperma fortunei under experimental conditions. Iheringia. Série Zool. 98, 66-69. doi: 10.1590/S0073-47212008000100009

Atkinson, C. L., Julian, J. P., and Vaughn, C. C. (2014). Species and function lost: role of drought in structuring stream communities. Biol. Conserv. 176, 30-38. doi: 10.1016/j.biocon.2014.04.029

Atkinson, C. L., Opsahl, S. P., Covich, A. P., Golladay, S. W., and Conner, L. M. (2010). Stable isotopic signatures, tissue stoichiometry, and nutrient cycling (C and N) of native and invasive freshwater bivalves. J. North Am. Benthol. Soc. 29, 496-505. doi: 10.1899/09-083.1

\section{CONCLUSION}

Our understanding of the causes and impacts of mass mortality events of invasive freshwater bivalves is developing, though several key questions remain. It remains unclear whether these are "black swan events" (sensu Anderson et al., 2017)-rare events that can have profound impacts on populations and ecosystems-or a regular feature of a community dominated by invasive species. Our ability to answer these questions will be important in creating a better understanding of how mass mortality events of invasive bivalve currently affect aquatic ecosystems, and how they will do so in the face of continued biotic homogenization and climate change. Because invasive bivalves are well-suited for manipulative studies, this faunal group can be used to further understand the trophic and non-trophic consequences of massive mortalities in aquatic ecosystems.

\section{AUTHOR CONTRIBUTIONS}

WM conceived of this study. WM and RS contributed to all other components of this study.

\section{FUNDING}

This work was supported by funding from the School of Science and Engineering at Merrimack College.

\section{ACKNOWLEDGMENTS}

Many colleagues provided comments on the early stages of this study following a presentation at the Society for Freshwater Science 2018 annual meeting. WH McDowell and KMS McDowell provided valuable feedback on drafts of this manuscript. Three reviewers also provided helpful feedback on this study. Finally, the establishment of this collaboration was aided by mentorship from JE Byers and a Research Coordination Network grant from the National Science Foundation.

Baker, S. M., and Levinton, J. S. (2003). Selective feeding by three native North American freshwater mussels implies food competition with zebra mussels. Hydrobiologia 505, 97-105. doi: 10.1023/B:HYDR.0000007298.52 250.99

Balogh, C., Muskó, I. B., László, G., and Nagy, L. (2008). “Quantitative trends of zebra mussels in Lake Balaton (Hungary) in 2003-2005 at different water levels," in Ecological Effects of Water-Level Fluctuations in Lakes, eds K. M. Wantzen, K.-O. Rothhaupt, M. Mörtl, M. Cantonati, L. G. Tóth, and P. Fischer (Dordrecht: Springer), 57-69. doi: 10.1007/978-1-4020-9192-6_7

Baxter, C. V., Fausch, K. D., and Carl Saunders, W. (2005). Tangled webs: reciprocal flows of invertebrate prey link streams and riparian zones. Freshw. Biol. 50, 201-220. doi: 10.1111/j.1365-2427.2004. 01328.x

Blakeslee, A. M., Altman, I., Miller, A. W., Byers, J. E., Hamer, C. E., and Ruiz, G. M. (2012). Parasites and invasions: a biogeographic examination of parasites and hosts in native and introduced ranges. J. Biogeogr. 39, 609-622. doi: 10.1111/j.1365-2699.2011.02631.x

Blakeslee, A. M., Byers, J. E., and Lesser, M. P. (2008). Solving cryptogenic histories using host and parasite molecular genetics: the resolution of 
Littorina littorea's North American origin. Mol. Ecol. 17, 3684-3696. doi: 10.1111/j.1365-294X.2008.03865.X

Blumenshine, S. C., Vadeboncoeur, Y., Lodge, D. M., Cottingham, K. L., and Knight, S. E. (1997). Benthic-pelagic links: responses of benthos to water-column nutrient enrichment. J. North Am. Benthol. Soc. 16, 466-479. doi: $10.2307 / 1468138$

Bódis, E., Tóth, B., Borza, P., Ács, É., Szekeres J, and Sousa, R. (2014b). Empty native and invasive bivalve shells as benthic habitat modifiers in a large river. Limnologica 49, 1-9. doi: 10.1016/j.limno.2014.07.002

Bódis, E., Tóth, B., and Sousa, R. (2014a). Massive mortality of invasive bivalves as a potential resource subsidy for the adjacent terrestrial food web. Hydrobiologia 735, 253-262. doi: 10.1007/s10750-013-1445-5

Bódis, E., Tóth, B., and Sousa, R. (2016). - Freshwater mollusc assemblages and habitat associations in the Danube River Drainage, Hungary. Aquat. Conserv. 26, 319-332. doi: 10.1002/aqc.2585

Boltovskoy, D., Correa, N., Cataldo, D., and Sylvester, F. (2006). Dispersion and ecological impact of the invasive freshwater bivalve Limnoperna fortunei in the Río de la Plata watershed and beyond. Biol. Invasions 8, 947-963. doi: $10.1007 /$ s10530-005-5107-z

Burreson, E. M., and Ragone, C. (1996). Epizootiology of Perkinsus marinus disease of oysters in Chesapeake Bay, with emphasis on data since 1985. J. Shellf. Res. $15,17-34$.

Caraco, N. F., Cole, J. J., Raymond, P. A., Strayer, D. L., Pace, M. L., Findlay, S. E., et al. (1997). Zebra mussel invasion in a large, turbid river: phytoplankton response to increased grazing. Ecology 78, 588-602. doi: 10.1890/00129658(1997)078[0588:ZMIIAL]2.0.CO;2

Carella, F., Villari, G., Maio, N., and De Vico, G. (2016). Disease and disorders of freshwater unionid mussels: a brief overview of recent studies. Front. Physiol. 7:489. doi: 10.3389/fphys.2016.00489

Castañeda, R. A., Cvetanovska, E., Hamelin, K. M., Simard, M. A., and Ricciardi, A. (2018). Distribution, abundance and condition of an invasive bivalve (Corbicula fluminea) along an artificial thermal gradient in the St. Lawrence River. Aquat. Invasions 13, 379-392. doi: 10.3391/ai.2018.13.3.06

Cherry, D. S., Scheller, J. L., Cooper, N. L., and Bidwell, J. R. (2005). Potential effects of Asian clam (Corbicula fluminea) die-offs on native freshwater mussels (Unionidae) I: water-column ammonia levels and ammonia toxicity. J. North Am. Benthol. Soc. 24, 369-380. doi: 10.1899/04-073.1

Christian, A. D., Crump, B. G., and Berg, D. J. (2008). Nutrient release and ecological stoichiometry of freshwater mussels (Mollusca: Unionidae) in 2 small, regionally distinct streams. J. North Am. Benthol. Soc. 27, 440-450. doi: 10.1899/07-112.1

Churchill, C. J. (2013). Spatio-temporal spawning and larval dynamics of a zebra mussel (Dreissena polymorpha) population in a North Texas Reservoir: implications for invasions in the southern United States. Aquat. Invasions 8, 389-406. doi: 10.3391/ai.2013.8.4.03

Churchill, C. J., Hoeinghaus, D. J., and La Point, T. W. (2017). Environmental conditions increase growth rates and mortality of zebra mussels (Dreissena polymorpha) along the southern invasion front in North America. Biol. Invasions 19, 2355-2373. doi: 10.1007/s10530-017-1447-8

Cooper, N. L., Bidwell, J. R., and Cherry, D. S. (2005). Potential effects of Asian clam (Corbicula fluminea) die-offs on native freshwater mussels (Unionidae) II: porewater ammonia. J. North Am. Benthol. Soc. 24, 381-394. doi: 10.1899/04-074.1

Covich, A. P., Palmer, M. A., and Crowl, T. A. (1999). The role of benthic invertebrate species in freshwater ecosystems: zoobenthic species influence energy flows and nutrient cycling. Bioscience 49, 119-127. doi: 10.2307/ 1313537

Crespo, D., Dolbeth, M., Leston, S., Sousa, R., and Pardal, M. A. (2015). Distribution of Corbicula fluminea in the invaded range: a geographic approach with notes on species traits variability. Biol. Invasions 17, 2087-2101. doi: 10.1007/s10530-015-0862-y

de Bello, F., Lavorel, S., Díaz, S., Harrington, R., Cornelissen, J. H., Bardgett, R. D., et al. (2010). Towards an assessment of multiple ecosystem processes and services via functional traits. Biodivers. Conserv. 19, 2873-2893. doi: 10.1007/s10531-010-9850-9

DuBose, T. P., Atkinson, C. L., Vaughn, C. C., and Golladay, S. W. (2019). Droughtinduced, punctuated loss of freshwater mussels alters ecosystem function across temporal scales. Front. Ecol. Evol. 7:274. doi: 10.3389/fevo.2019.00274
Dudgeon, D., and Morton, B. (1983). The population dynamics and sexual strategy of Anodonta woodiana (Bivalvia: unionacea) in Plover Cove Reservoir, Hong Kong. J. Zool. 201, 161-183. doi: 10.1111/j.1469-7998.1983.tb0 4268.x

Feng, X., and Papeş, M. (2017). Physiological limits in an ecological niche modeling framework: a case study of water temperature and salinity constraints of freshwater bivalves invasive in USA. Ecol. Modell. 346, 48-57. doi: 10.1016/j.ecolmodel.2016.11.008

Ferreira-Rodríguez, N., Akiyama, B. Y., Aksenova, O., Araujo, R., Barnhart, C., Bespalaya, Y., et al. (2019). Research priorities for freshwater mussel conservation assessment. Biol. Conserv. 231, 77-87. doi: 10.1016/j.biocon.2019.01.002

Ferreira-Rodríguez, N., and Pardo, I. (2016). An experimental approach to assess Corbicula fluminea (Müller, 1774) resistance to osmotic stress in estuarine habitats. Estuar. Coast. Shelf. Sci. 176, 110-116. doi: 10.1016/j.ecss.2016.04.017

Ferreira-Rodríguez, N., Sousa, R., and Pardo, I. (2018). Negative effects of Corbicula fluminea over native freshwater mussels. Hydrobiologia 810, 85-95. doi: 10.1007/s10750-016-3059-1

Fey, S. B., Siepielski, A. M., Nusslé, S., Cervantes-Yoshida, K., Hwan, J. L., Huber, E. R., et al. (2015). Recent shifts in the occurrence, cause, and magnitude of animal mass mortality events. Proc. Natl. Acad. Sci. U. S. A. 112, 1083-1088. doi: 10.1073/pnas.1414894112

Foekema, E. M., Hulst, O. V., and Reeze, B. (2008). Massale sterfte onder Aziatische korfmosselen in de Maas. $\mathrm{H}_{2} \mathrm{O}$ 41, 45-48. Available online at: https://library. wur.nl/WebQuery/wurpubs/488135

Gagnon, P. M., Golladay, S. W., Michener, W. K., and Freeman, M. C. (2004). Drought responses of freshwater mussels (Unionidae) in coastal plain tributaries of the Flint River basin, Georgia. J. Freshw. Ecol. 19, 667-679. doi: 10.1080/02705060.2004.9664749

Golladay, S. W., Gagnon, P., Kearns, M., Battle, J. M., and Hicks, D. W. (2004). Response of freshwater mussel assemblages (Bivalvia: Unionidae) to a record drought in the Gulf Coastal Plain of southwestern Georgia. J. North Am. Benthol. Soc. 23, 494-506. doi: 10.1899/08873593(2004)023and<0494:ROFMABand >2.0.CO;2

Gomes, C., Sousa, R., Mendes, T., Borges, R., Vilares, P., Vasconcelos, V., et al. (2016). Low genetic diversity and high invasion success of Corbicula fluminea (Bivalvia, Corbiculidae)(Müller, 1774) in Portugal. PLoS ONE 11:e0158108. doi: 10.1371/journal.pone.0158108

Grazio, J. L., and Montz, G. (2002). "Winter lake drawdown as a strategy for zebra mussel (Dreissena polymorpha) control: results of pilot studies in Minnesota and Pennsylvania," in Proceedings 11th International Conference on Aquatic Invasive Species (Alexandria, VA: US Army Engineer Research and Development Center), 207-217.

Haag, W. R. (2012). North American Freshwater Mussels: Natural History, Ecology, and Conservation. Cambridge: Cambridge University Press. doi: 10.1017/CBO9781139048217

Haag, W. R., and Warren, M. L. Jr. (2008). Effects of severe drought on freshwater mussel assemblages. Trans. Am. Fish. Soc. 137, 1165-1178. doi: 10.1577/T07-100.1

Helfield, J. M., and Naiman, R. J. (2002). Salmon and alder as nitrogen sources to riparian forests in a boreal Alaskan watershed. Oecologia 133, 573-582. doi: 10.1007/s00442-002-1070-x

Hellmann, J. J., Byers, J. E., Bierwagen, B. G., and Dukes, J. S. (2008). Five potential consequences of climate change for invasive species. Conserv. Biol. 22, 534-543. doi: 10.1111/j.1523-1739.2008.00951.x

Hocking, M. D., and Reynolds, J. D. (2011). Impacts of salmon on riparian plant diversity. Science 331, 1609-1612. doi: 10.1126/science.1201079

Ilarri, M., Freitas, F., Costa-Dias, S., Antunes, C., Guilhermino, L., and Sousa, R. (2012). Associated macrozoobenthos with the invasive Asian clam Corbicula fluminea. J. Sea Res. 72, 113-120. doi: 10.1016/j.seares.2011. 10.002

Ilarri, M. I., Amorim, L., Souza, A. T., and Sousa, R. (2018). Physical legacy of freshwater bivalves: effects of habitat complexity on the taxonomical and functional diversity of invertebrates. Sci. Total Environ. 634, 1398-1405. doi: 10.1016/j.scitotenv.2018.04.070

Ilarri, M. I., Antunes, C., Guilhermino, L., and Sousa, R. (2011). Massive mortality of the Asian clam Corbicula fluminea in a highly invaded area. Biol. Invasions 13, 277-280. doi: 10.1007/s10530-010-9833-5 
Ilarri, M. I., Souza, A. T., Amorim, L., and Sousa, R. (2019). Decay and persistence of empty bivalve shells in a temperate riverine system. Sci. Tot. Environ. 683, 185-192. doi: 10.1016/j.scitotenv.2019.05.208

Ilarri, M. I., Souza, A. T., Antunes, C., Guilhermino, L., and Sousa, R. (2014). Influence of the Asian clam Corbicula fluminea (Bivalvia: Corbiculidae) on estuarine epibenthic assemblages. Estuar. Coastal Shelf Sci. 143, 12-19. doi: 10.1016/j.ecss.2014.03.017

Ilarri, M. I., Souza, A. T., and Sousa, R. (2015). Contrasting decay rates of freshwater bivalves' shells: aquatic versus terrestrial habitats. Limnol. Ecol. Manag. Inland Waters 51, 8-14. doi: 10.1016/j.limno.2014.10.002

Karatayev, A. Y., Boltovskoy, D., Padilla, D. K., and Burlakova, L. E. (2007). The invasive bivalves Dreissena polymorpha and Limnoperna fortunei: parallels, contrasts, potential spread and invasion impacts. J. Shellf. Res. 26, 205-214. doi: 10.2983/0730-8000(2007)26[205:TIBDPA]2.0.CO;2

Lacoste, A., Jalabert, F., Malham, S., Cueff, A., Gélébart, F., Cordevant, C., et al. (2001). A Vibrio splendidus strain is associated with summer mortality of juvenile oysters Crassostrea gigas in the Bay of Morlaix (North Brittany, France). Dis. Aquat. Org. 46, 139-145. doi: 10.3354/dao046139

Lauer, T. E., and Spacie, A. (2004). Space as a limiting resource in freshwater systems: competition between zebra mussels (Dreissena polymorpha) and freshwater sponges (Porifera). Hydrobiologia 517, 137-145. doi: 10.1023/B:HYDR.0000027342.31716.9a

Lee, T., Siripattrawan, S., Ituarte, C. F., and Foighil, D. Ó. (2005). Invasion of the clonal clams: Corbicula lineages in the New World. Am. Malacol. Bull. 20, 113-122.

Leff, L. G., Burch, J. L., and McArthur, J. V. (1990). Spatial distribution, seston removal, and potential competitive interactions of the bivalves Corbicula fluminea and Elliptio complanata, in a coastal plain stream. Freshw. Biol. 24, 409-416. doi: 10.1111/j.1365-2427.1990.tb00720.x

Lester, P. J., and Gruber, M. A. (2016). Booms, busts and population collapses in invasive ants. Biol. Invasions 18, 3091-3101. doi: 10.1007/s10530-016-1214-2

Leuven, R. S., Collas, F. P., Koopman, K. R., Matthews, J., and van der Velde, G. (2014). Mass mortality of invasive zebra and quagga mussels by desiccation during severe winter conditions. Aquatic Invasions 9, 243-252. doi: 10.3391/ai.2014.9.3.02

Lopes-Lima, M., Burlakova, L. E., Karatayev, A. Y., Mehler, K., Seddon, M., and Sousa, R. (2018). - Conservation of freshwater bivalves at the global scale: diversity, threats and research needs. Hydrobiologia 810, 1-14. doi: 10.1007/s10750-017-3486-7

Lopes-Lima, M., Sousa, R., Geist, J., Aldridge, D. C., Araujo, R., Bergengren, J., et al. (2017). Conservation status of freshwater mussels in Europe: state of the art and future challenges. Biol. Rev. 92, 572-607. doi: 10.1111/brv.12244

Matthews, M. A., and McMahon, R. F. (1999). Effects of temperature and temperature acclimation on survival of zebra mussels (Dreissena polymorpha) and Asian clams (Corbicula fluminea) under extreme hypoxia. J. Mollusc. Stud. 65, 317-325. doi: 10.1093/mollus/65.3.317

McDowell, W. G., Benson, A. J., and Byers, J. E. (2014). Climate controls the distribution of a widespread invasive species: implications for future range expansion. Freshw. Biol. 59, 847-857. doi: 10.1111/fwb.12308

McDowell, W. G., and Byers, J. E. (2019). High abundance of an invasive species gives it an outsized ecological role. Freshw. Biol. 64, 577-586. doi: $10.1111 /$ fwb. 13243

McDowell, W. G., McDowell, W. H., and Byers, J. E. (2017). Mass mortality of a dominant invasive species in response to an extreme climate event: implications for ecosystem function. Limnol. Oceanogr. 62, 177-188. doi: 10.1002/lno.10384

McGill, B. J., Enquist, B. J., Weiher, E., and Westoby, M. (2006). Rebuilding community ecology from functional traits. Trends Ecol. Evol. 21, 178-185. doi: $10.1016 /$ j.tree.2006.02.002

McMahon, R. F. (2002). Evolutionary and physiological adaptations of aquatic invasive animals: r selection versus resistance. Can. J. Fish. Aquat. Sci. 59, 1235-1244. doi: 10.1139/f02-105

McMahon, R. F., and Bogan, A. E. (2001). "Mollusca: Bivalvia. Chapter 11," in Ecology and Classification of North American Freshwater Invertebrates, eds J. H. Thorp and A. P. Covich (New York, NY: Academic Press), doi: 10.1016/B978-012690647-9/50012-0

Modesto, V., Castro, P., Lopes-Lima, M., Antunes, C., Ilarri, M., and Sousa, R. (2019). Potential impacts of the invasive species Corbicula fluminea on the survival of glochidia. Sci. Tot. Environ. 673, 157-164. doi: 10.1016/j.scitotenv.2019.04.043

Moore, J. W., Herbst, D. B., Heady, W. N., and Carlson, S. M. (2012). Stream community and ecosystem responses to the boom and bust of an invading snail. Biol. Invasions 14, 2435-2446. doi: 10.1007/s10530-012-0240-y

Mouthon, J. (2001). Life cycle and population dynamics of the Asian clam Corbicula fluminea (Bivalvia: Corbiculidae) in the Saone and Rhone rivers (France). Ann. Limnol. Int. J. Lim. 39, 15-25. doi: 10.1051/limn/2003001

Mouthon, J., and Daufresne, M. (2006). Effects of the 2003 heatwave and climatic warming on mollusc communities of the Saône: a large lowland river and of its two main tributaries (France). Glob. Change Biol. 12, 441-449. doi: 10.1111/j.1365-2486.2006.01095.x

Mundie, J. H., Simpson, K. S., and Perrin, C. J. (1991). Responses of stream periphyton and benthic insects to increases in dissolved inorganic phosphorus in a mesocosm. Can. J. Fish. Aquat. Sci. 48, 2061-2072. doi: 10.1139/f91-245

Novais, A., Batista, D., Cássio, F., Pascoal, C., and Sousa, R. (2017). Effects of invasive clam (Corbicula fluminea) die-offs on the structure and functioning of freshwater ecosystems. Freshw. Biol. 62, 1908-1916. doi: 10.1111/fwb.13033

Novais, A., Souza, A., Ilarri, M., Pascoal, C., and Sousa, R. (2015). Facilitation in the low intertidal: effects of an invasive species on the structure of an estuarine macrozoobenthic assemblage. Mar. Ecol. Prog. Ser. 522, 157-167. doi: 10.3354/meps11168

Nowlin, W. H., Vanni, M. J., and Yang, L. H. (2008). Comparing resource pulses in aquatic and terrestrial ecosystems. Ecology 89, 647-659. doi: 10.1890/07-0303.1

Oduor, A. M., Leimu, R., and van Kleunen, M. (2016). Invasive plant species are locally adapted just as frequently and at least as strongly as native plant species. J. Ecol. 104, 957-968. doi: 10.1111/1365-2745. 12578

Parker, I. M., Simberloff, D., Lonsdale, W. M., Goodell, K., Wonham, M., Kareiva, P. M., et al. (1999). Impact: toward a framework for understanding the ecological effects of invaders. Biol. Invasions 1, 3-19. doi: 10.1023/A:1010034312781

Penk, M. R., and Williams, M. (2019). Thermal effluents from power plants boost performance of the invasive clam Corbicula fluminea in Ireland's largest river. Sci. Total Environ. 693:133546. doi: 10.1016/j.scitotenv.2019.07.352

Ricciardi, A. (1998). Global range expansion of the Asian mussel Limnoperna fortunei (Mytilidae): another fouling threat to freshwater systems. Biofouling 13, 97-106. doi: 10.1080/08927019809378374

Sakai, A. K., Allendorf, F. W., Holt, J. S., Lodge, D. M., Molofsky, J., With, K. A., et al. (2001). The population biology of invasive species. Annu. Rev. Ecol. Syst. 32, 305-332. doi: 10.1146/annurev.ecolsys.32.081501.114037

Simard, M. A., Paquet, A., Jutras, C., Robitaille, Y., Blier, P. U., Courtois, R., et al. (2012). North American range extension of the invasive Asian clam in a St. Lawrence River power station thermal plume. Aquat. Invasions 7, 81-89. doi: 10.3391/ai.2012.7.1.009

Smith, B. J., Harris, B. S., Harris, T. J., LaBudde, L. A., and Hayer, C. A. (2018) Status and trends of the Asian clam (Corbicula fluminea) in the lower Fox River and Green Bay. J. Great Lakes Res. 44, 943-949. doi: 10.1016/j.jglr.2018. 02.012

Sousa, R., Ferreira, A., Carvalho, F., Lopes-Lima, M., Varandas, S., and Teixeira, A. (2018). Die-offs of the endangered pearl mussel Margaritifera margaritifera during an extreme drought. Aquat. Conserv. 28, 1244-1248. doi: 10.1002 /aqc. 2945

Sousa, R., Freire, R., Rufino, M., Méndez, J., Gaspar, M., Antunes, C., et al. (2007). Genetic and shell morphological variability of the invasive bivalve Corbicula fluminea (Müller, 1774) in two Portuguese estuaries. Estuar. Coast. Shelf Sci. 74, 166-174. doi: 10.1016/j.ecss.2007.04.011

Sousa, R., Gutiérrez, J. L., and Aldridge, D. C. (2009). Non-indigenous invasive bivalves as ecosystem engineers. Biol. Invasions 11, 2367-2385 doi: 10.1007/s10530-009-9422-7

Sousa, R., Novais, A., Costa, R., and Strayer, D. L. (2014). Invasive bivalves in fresh waters: impacts from individuals to ecosystems and possible control strategies. Hydrobiologia 735, 233-251. doi: 10.1007/s10750-012-1409-1

Sousa, R., Varandas, S., Cortes, R., Teixeira, A., Lopes-Lima, M., Machado, J., et al. (2012). "Massive die-offs of freshwater bivalves as resource pulses," in Annales de Limnologie-International Journal of Limnology, Vol. 48 (EDP Sciences), 105-112. doi: 10.1051/limn/2012003 
Stott, I., Franco, M., Carslake, D., Townley, S., and Hodgson, D. (2010). Boom or bust? A comparative analysis of transient population dynamics in plants. J. Ecol. 98, 302-311. doi: 10.1111/j.1365-2745.2009.01632.x

Strayer, D. L. (1999). Use of flow refuges by unionid mussels in rivers. J. North Am. Benthological Soc. 18, 468-476. doi: 10.2307/1468379

Strayer, D. L., Caraco, N. F., Cole, J. J., Findlay, S., and Pace, M. L. (1999). Transformation of freshwater ecosystems by bivalves: a case study of zebra mussels in the Hudson River. Bioscience 49, 19-27. doi: 10.2307/ 1313490

Strayer, D. L., D’Antonio, C. M., Essl, F., Fowler, M. S., Geist, J., Hilt, S., et al. (2017). Boom-bust dynamics in biological invasions: towards an improved application of the concept. Ecol. Lett. 20, 1337-1350. doi: 10.1111/ele. 12822

Strayer, D. L., Downing, J. A., Haag, W. R., King, T. L., Layzer, J. B., Newton, T. J., et al. (2004). Changing perspectives on pearly mussels, North America's most imperiled animals. Bioscience 54, 429-439. doi: 10.1641/00063568(2004)054[0429:CPOPMN]2.0.CO;2

Strayer, D. L., and Malcom, H. M. (2006). Long-term demography of a zebra mussel (Dreissena polymorpha) population. Freshw. Biol. 51, 117-130. doi: 10.1111/j.1365-2427.2005.01482.x

Strayer, D. L., and Malcom, H. M. (2007). Shell decay rates of native and alien freshwater bivalves and implications for habitat engineering. Freshw. Biol. 52, 1611-1617. doi: 10.1111/j.1365-2427.2007.01792.x

Strayer, D. L., and Malcom, H. M. (2018). Long-term responses of native bivalves (Unionidae and Sphaeriidae) to a Dreissena invasion. Freshw. Sci. 37, 697-711. doi: $10.1086 / 700571$

Subalusky, A. L., Dutton, C. L., Rosi, E. J., and Post, D. M. (2017). Annual mass drownings of the Serengeti wildebeest migration influence nutrient cycling and storage in the Mara River. Proc. Natl. Acad. Sci. U.S.A. 114, 7647-7652. doi: $10.1073 /$ pnas. 1614778114

Sylvester, F., D., Boltovskoy, and Cataldo, D. (2007). Fast response of freshwater consumers to a new trophic resource: Predation on the recently introduced Asian bivalve Limnoperna fortunei in the lower Parana river, South America. Austral Ecol. 32, 403-415. doi: 10.1111/j.1442-9993.2007.01707.x

Trenberth, K. E. (2011). Changes in precipitation with climate change. Clim. Res. 47, 123-138. doi: 10.3354/cr00953

Vaughn, C. C. (2018). Ecosystem services provided by freshwater mussels. Hydrobiologia 810, 15-27. doi: 10.1007/s10750-017-3139-x
Vaughn, C. C., Atkinson, C. L., and Julian, J. P. (2015). Drought-induced changes in flow regimes lead to long-term losses in mussel-provided ecosystem services. Ecol. Evol. 5, 1291-1305. doi: 10.1002/ece3.1442

Vaughn, C. C., and Hakenkamp, C. C. (2001). The functional role of burrowing bivalves in freshwater ecosystems. Freshw. Biol. 46, 1431-1446. doi: 10.1046/j.1365-2427.2001.00771.x

Vaughn, C. C., and Hoellein, T. J. (2018). Bivalve impacts in freshwater and marine ecosystems. Annu. Rev. Ecol. Evol. Syst. 49, 183-208. doi: 10.1146/annurev-ecolsys-110617-062703

Wenger, S. J., Subalusky, A. L., and Freeman, M. C. (2019). The missing dead: The lost role of animal remains in nutrient cycling in North American Rivers. Food Webs 18:e00106. doi: 10.1016/j.fooweb.2018.e00106

Werner, S., and Rothhaupt, K. O. (2008). "Mass mortality of the invasive bivalve Corbicula fluminea induced by a severe low-water event and associated low water temperatures," in Ecological Effects of Water-Level Fluctuations in Lakes, eds K. M. Wantzen, K.-O. Rothhaupt, M. Mörtl, M. Cantonati, L. G. Tóth, and P. Fischer (Dordrecht: Springer), 143-150. doi: 10.1007/978-1-4020-9192-6_14

White, J. D., Hamilton, S. K., and Sarnelle, O. (2015). Heat-induced mass mortality of invasive zebra mussels (Dreissena polymorpha) at sublethal water temperatures. Can. J. Fish. Aquat. Sci. 72, 1221-1229. doi: 10.1139/cjfas-2015-0064

Yang, L. H. (2004). Periodical cicadas as resource pulses in North American forests. Science 306, 1565-1567. doi: 10.1126/science.1103114

Zhu, B., Fitzgerald, D. G., Mayer, C. M., Rudstam, L. G., and Mills, E. L. (2006). Alteration of ecosystem function by zebra mussels in Oneida Lake: impacts on submerged macrophytes. Ecosystems 9, 1017-1028. doi: 10.1007/s10021-005-0049-y

Conflict of Interest Statement: The authors declare that the research was conducted in the absence of any commercial or financial relationships that could be construed as a potential conflict of interest.

Copyright (c) 2019 McDowell and Sousa. This is an open-access article distributed under the terms of the Creative Commons Attribution License (CC BY). The use, distribution or reproduction in other forums is permitted, provided the original author(s) and the copyright owner(s) are credited and that the original publication in this journal is cited, in accordance with accepted academic practice. No use, distribution or reproduction is permitted which does not comply with these terms. 